\title{
Development of Iron-Phosphorus Electrodeposition Bath for Soft Magnetic Films with High Saturation Magnetization
}

\author{
Madoka TAKAI*, Akiyoshi NAKAMURA*, \\ Fujio ASA* and Tetsuya OSAKA*
}

\section{高飽和磁化軟磁性用 FeP電析浴の開発}

\author{
高井まどか*, 中村明義*, 浅富士夫*, 逢坂哲彌*
}

Key Words : Electrodeposition, Soft Magnetic Properties, FeP Film

\section{Introduction}

Recently, demands have been made to develop soft magnetic materials with high saturation magnetization, due to the necessity to use the higher saturation magnetic induction film for the core of thin film head or inductive thin film head in order to use higher density magnetic recording.

For such a purpose, the films formed by the electroplating or electroless plating is superior to those formed by sputtering, because platings are able to form thicker film more than several $\mu \mathrm{m}$. High saturation magnetization materials by means of electroplating are reported by some papers ${ }^{1)-3)}$. On the basis of such circumstances, we focus on the electrodeposited Fe-based films due to its high saturation magnetization of iron element. Recently we succeeded to get the soft magnetic $\mathrm{FeP}$ film with high saturation magnetization by means of an electroplating method, and its film magnetic properties and microstructure were reported ${ }^{4}$.

In this letter, we report the development of its Fe-based electrodepodition bath with indicating several important factors of its bath and operating conditions.

\section{Experimental}

Test samples with $1.5 \mu \mathrm{m}$ thich were deposited on sputtered $\mathrm{Cu} / \mathrm{Cr}(150 / 30 \mathrm{~nm}$ thick $)$ on polished $\mathrm{NiP} / \mathrm{Al}$ substrate of a rigid magnetic disk substrate. This substrate was selected after comparing with three substrates, i. e., $\mathrm{Cu} / \mathrm{Cr} / \mathrm{NiP} / \mathrm{Al}$,

\footnotetext{
* School of Sci. and Eng. ; Kagami Memorial Lab. for Materials Sci. and Tech., Waseda Univ.(4-1 Okubo 3-chome, Shinjuku-ku, Tokyo 169, Japan

早稲田大学 理工学部 各務記念材料技術研究所
}

$8 \mu \mathrm{m}$ thick and $0.1 \mathrm{~mm}$ thick copper foils. The basic bath compositions and its operating conditions for electrodeposited $\mathrm{FeP}$ film were shown in Table 1. The substrate for electrodeposition was set in a RDE (rotating disk electrode) as the working electrode. A Pt mesh was used as a counter electrode. $\mathrm{A} \mathrm{Ag} / \mathrm{AgCl}$ was used as a reference electrode. The film composition was analyzed with an inductively coupled argon plasma atomic emission spectroscopy (ICP) and an electron micro-probe analysis (EPMA). $\mathrm{MH}$ loops were measured with a vibrating magnetometer equipped with an earth magnetic field compensation circuit (VSM). Structural properties were examined with X-ray diffractometer (XRD, Fe-K $\alpha$ ).

\section{Results and Discussionp}

The bath composition for electrodeposited FeP film was optimized as shown in Table 1. Since iron (II) sulfate is used for the iron element source, ascorbic acid is added to prevent oxidation of ferrous ion. The concentration of ascorbic acid is higher than an usual case, thus it might work not only as preventing oxidation of ferrous ion, but also as the other factor. Sodium

Table 1 Basic bath compositions and operating conditions for electrodeposited $\mathrm{FeP}$ films.

\begin{tabular}{l|c}
\hline \multicolumn{1}{c|}{ Chemicals } & Concentration $\left[\mathrm{mol} \mathrm{dm}^{-3}\right]$ \\
\hline $\mathrm{FeSO}_{4} \cdot 7 \mathrm{H}_{2} \mathrm{O}$ & 1.0 \\
$\left(\mathrm{NH}_{4}\right)_{2} \mathrm{SO}$ & 0.1 \\
$\mathrm{C}_{6} \mathrm{H}_{7} \mathrm{O}_{6}$ & 0.1 \\
$\mathrm{NaH}_{2} \mathrm{PO}_{2} \cdot \mathrm{H}_{2} \mathrm{O}$ & 0.01 \\
\hline Current density & $10 \mathrm{~mA} \mathrm{~cm}^{-2}$ \\
Rotation per minute & $1000 \mathrm{rpm}$ \\
Bath temperature & room temp. \\
Bath pH & 2.5 \\
\hline
\end{tabular}



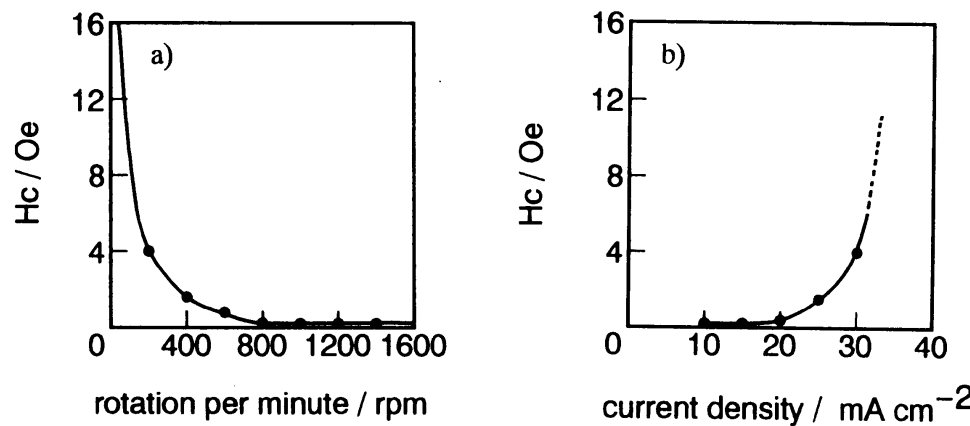

Fig. 1 The effect of rotation per minute of RDE (a) and current density (b) on $H c$ of electrodeposited $\mathrm{FeP}$ films with $1.5 \mu \mathrm{m}$ thick perpared by $10 \mathrm{~mA} \mathrm{~cm}^{-2}$ and at $1000 \mathrm{rpm}$.

phosphinate is used for the source of codepositing phosphorus into the film. Sodium phosphinate 0.005 and $0.1 \mathrm{~mol} \mathrm{dm}^{-3}$ makes the coercivity, $\mathrm{Hc}$, of $\mathrm{FeP}$ film lower. Ammonium sulfate is used as buffer reagent.

The hydrodynamics of plating solution and the current density greatly affect the soft magnetic properties of $\mathrm{FeP}$ films as indicated in Fig. 1 ( $\mathrm{a}, \mathrm{b})$. The Hc of electrodeposited FeP film without rotation of disk electrode becomes about 200e, however, the Hc decreases with increasing a rotation speed. The lowest $\mathrm{Hc}$ value of $0.20 \mathrm{e}$ was attained at more than $800 \mathrm{rpm}$ at as-deposited conditions. Since the unstable deposition potential became stable at more than $800 \mathrm{rpm}$, the faster hydrodynamics conditions might stabilize the interface $\mathrm{pH}$ condition, and also extract hydrogen gas evolution.

The effect of current density on $\mathrm{Hc}$ is so clear as is seen in Fig. 1(b). So lower Hc value of $0.2 \mathrm{Oe}$ drastically increases at the region more than 30 $\mathrm{mA} \mathrm{cm}{ }^{-2}$, at $1000 \mathrm{rpm}$. Fig.2 demonstrates a representative $\mathrm{MH}$ loop for $\mathrm{FeP}$ soft magnetic film, where the saturation magnetization and film composition were $140 \mathrm{emu} \mathrm{g}^{-1}(1.4 \mathrm{~T})$ and $80 \mathrm{at} \% \mathrm{Fe}-20 \mathrm{at}$

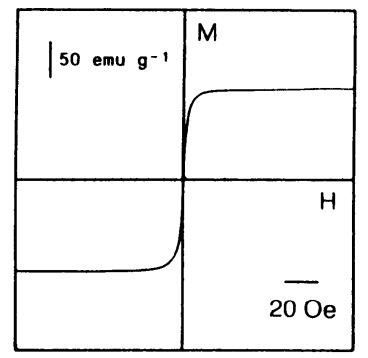

Fig. 2 Representative MH loop of electrodeposited FeP film with $1.5 \mu \mathrm{m}$ thick.
$\% \mathrm{P}$, respectively. The results of XRD analysis for the $\mathrm{FeP}$ films prepared with less than $25 \mathrm{~mA}$ $\mathrm{cm}^{-2}$ displayed no peaks except for those of $\mathrm{Cu}$ substrate. The most suitable soft magnetic $\mathrm{FeP}$ film was suggested to be an amorphous state or hyper-fine crystalline structure indicated by TEM results ${ }^{4}$.

The species of substrates also affects strongly the soft magnetic properties. The most suitable soft magnetic properties of $\mathrm{FeP}$ film are given by using $\mathrm{Cu} / \mathrm{Cr} / \mathrm{NiP} / \mathrm{Al}$ substrate when comparing other two $\mathrm{Cu}$ foil substrates. However, the XRD and TEM results give no difference among three substrates. Thus, the most suitable soft magnetic properties might come from the other important factor on the basis of amorphous or hyperfine crystalline structure.

\section{Conclusion}

By selecting some factors of plating bath, the soft magnetic $\mathrm{FeP}$ film with high saturation magnetization at as-deposited conditions without external magnetic field was developed. A faster hydrodynamics condition, a lower current density and a selection of substrate are the most important factors to obtain the soft magnetic properties for $\mathrm{FeP}$ films, even though the bath composition is determined.

(Received February 2, 1994 ; Accepted March 14, 1994)

\section{References}

1) J. W. Chang, P. C. Andricacos, B. Petek, L. T. Romankiw, Extended Abstract of ; Electrochem. Soc. Fall Meeting, 892, 305 (1989)

2) Y. Omata ; IEEE Trans. J. Mag., Soc. Jpn., 5, 17 (1990)

3 ) O. Shinoura ; J. Surf. Finish. Soc. Jpn., 44, 1114 (1993)

4) T. Osaka, M. Takai, A. Nakamura and F. Asa ; Denki Kagaku, in press 